\title{
Cuts force UK universities into "glamorous" medical research
}

\section{London}

MEDICAL research in British universities has been damaged and distorted by government spending cutbacks in research councils and education, the Committee of Vice-Chancellors and Principals says in evidence prepared for the House of Lord Select Committee on Science and Technology.

Clinical academic staff numbers have dropped by 12.5 per cent since 1981 , equivalent to the loss of at least one medical school, according to a quoted survey by the National Association of Health Authorities. "Posts have been downgraded and chairs lost", the vice-chancellors' committee says. "Research has suffered as clinical academic staff understandably put their obligations to patient care and teaching first."

Much of British clinical medical research is carried out in the universities, financed by the University Grants Committee (UGC), the Medical Research Council (MRC), medical charities and foundations, and industry. UGC funding has declined in real terms, and the research councils are also facing financial stringencies; as a result, universities have been relying increasingly on private money. But grants from charities and foundations rarely provide for indirect costs, which must be met from university funds which have already been cut.

"There is a tendency for research to be distorted towards glamorous high-tech projects which attract outside funding from medical charities and industry at the expense of work likely to lead to greater benefit for the greater number of people", the vice-chancellor's committee says. This "tied" money from the charities and the pharmaceutical industry limits opportunities for innovative, creative research.

The MRC is also increasingly attempting to provide support to specific priority areas, according to the committee; it is no longer able to fund all the alpha-rated research projects submitted to it.

The vice-chancellor's committee's evidence on medical research (like that of the Association of Clinical Professors of Medicine, see Nature 327, 180; 1987) was to have been given to the House of Lords last week, but the hearing was cancelled because of the impending election.

Meanwhile, the committee is continuing to fight a battle with the Secretary of State for Education, Mr Kenneth Baker, over the pay of clinical academic staff. The government has allocated $£ 3.25$ million for this year's salary award for clinical academic staff, but the vice-chancellors' committee has refused to pay out the money until it receives an assurance that the funds will be built into universities' baseline funding for future years.

Vice-chancellors have threatened that they may not be able to pay the clinical academic staff at the government-decreed level, and may instead seek to negotiate clinical salaries on the basis of universities' ability to pay.

"Universities are no longer willing to subsidize clinical work at the expense of other university work", Mr Maurice Shock, chairman of the committee, told Mr Baker.

\section{A moratorium on pork-barrel funds Washington}

AFTER a lengthy and contentious debate, the 56 member institutions of the American Association of Universities (AAU) have agreed, by a vote of about four to one, not to accept 'pork barrel' funds, money which Congress votes directly to particular institutions, bypassing the usual funding agencies and their peer review procedures. The vote is said to be "morally binding", but AAU has no powers of enforcement, and there is sure to be opposition both in Congress and among some non-AAU universities.

The AAU, an organization mostly of well-known research universities including MIT, Yale, Stanford and Cornell, adheres to the philosophy that funds should be allocated strictly according to scientific merit, but this notion has been opposed by smaller universities, which claim, with some historical evidence, that it tends to keep the rich rich and the poor poor. Through the efforts of interested congressmen, a number of large projects have recently been awarded to universities of no great scientific renown (Wichita State and the University of Nevada at Las Vegas are two of the chief beneficiaries, but some AAU members have also profited).

The AAU decision is thus a small tussle in a complex three-way battle. With money hard to obtain, universities differ on the priorities of allocation; at the same time, Congress sees itself as having a responsibility to oversee science funding with more than purely scientific considerations in mind. The AAU made it clear that it did not want to its decision to be seen as a challenge to congressional authority, but some of the votes against the moratorium were for precisely that reason.

David Lindley

ment of Industry, Trade and Commerce (DITAC) emerged relatively unscathed. Some areas even received increases. In the opinion of Professor Ron Johnson, director of the Institute for Technology and Social Change at the University of Wollongong, the cuts are another sign to the CSIRO and the universities that the government wants them to develop links with industry more rapidly and to concentrate on more economically relevant research. He believes the government wants an increasing fraction of research supported through the Department of Industry, Trade and Commerce.

One thing seems certain in the light of the May cuts, and that is that the A\$50 million in additional funding for the ARC recommended by ASTEC is unlikely to be forthcoming. As Chris Burgess put it, the chances are "somewhere between zero and none".

Charles Morgan 